\title{
BOM JESUS DA CANA VERDE
}

\author{
Bom Jesus da Cana Verde
}

Daniel Afonso da Silva*

LINO, Anderson. Bom Jesus da Cana Verde: conflitos e celebrações no Norte do Paraná, 1886-2008. São Paulo: Belacop Livros, 2011.

A romaria em culto ao Senhor Bom Jesus da Cana Verde, na pequena Siqueira Campos, no norte pioneiro do Paraná, é dos maiores e mais marcantes acontecimentos religiosos do país. A cada agosto, milhares de fiéis e curiosos, do Brasil e do exterior, invadem a cidade para render devoção à imagem do santo hospedada no santuário da igreja matriz. $\mathrm{O}$ que a maior parte dos romeiros e passantes provavelmente nem desconfia é que a imagem e a festa em seu elogio, que existe desde 1934, derivam de disputas e conflitos depositários de modificações estruturais na relação de estado e igreja em todo o mundo ocidental ao longo dos últimos cento e cinquenta anos. O desvelamento dessas tensões e mutações, no que concerne ao Paraná e ao Brasil, é o objeto do ambicioso Bom Jesus da Cana Verde: conflitos e celebrações no Norte do Paraná, 1886-2008, de Anderson Lino.

Filho de Siqueira Campos e conjuntamente entusiasmado e perplexo com o fenômeno que é a festa em louvor ao Senhor Bom Jesus, Anderson Lino, fartamente respaldado em fontes primárias inéditas e fontes secundárias pouco consultadas, reconstitui os momentos decisivos da trajetória da imagem do santo. Seus pontos de partida e chegada são o tiroteio que teve lugar no Arraial dos Pintos, povoado da então colônia mineira, em seguida Siqueira Campos, em 1933. Esse incidente redefiniu a geografia política de poder na microrregião.

No dia 26 de abril de 1933, Alfredo Simon, vigário do distrito de Salto do Itararé, município de São José da Boa Vista, rumou para o Arraial

\footnotetext{
“Doutor em História Social pela Universidade de São Paulo. daniel.afonso@usp.br
} 
dos Pintos, na localidade de Murzilhos, com objetivo de destituir a imagem do Senhor Bom Jesus da posse da família Pinto e incorporá-la ao acervo da igreja. Escoltado por mais de vinte homens armados e determinados, o clérigo encontrou imensa resistência da comunidade local. Houve troca de desagravos, agressão e tiros. Um comerciante foi morto. O dono da imagem, Zeca Pinto, foi baleado e morreu em decorrência meses depois. Mas, por fim, o pároco Simon teve êxito: carregou a imagem.

Tendo participado do ocorrido, o prefeito da colônia mineira, Antonio Pereira José, que era advogado, abriu disputa judicial em favor de Zeca Pinto e da restituição da imagem do santo ao município.

Em plano mais detalhado, a ação do vigário do Salto do Itararé, evidencia Anderson Lino, esteve fundada em certa interpretação das novas diretrizes do direito canônico, instituídas em 1917, que impunham a monopolização, por parte da igreja, do "poder simbólico" expresso, por exemplo, em imagens de santos. A decorrência natural da norma foi a imposição de expropriação desses pertences do poderio de particulares. Assim o vigário fez. E, por claro oportunismo, depositou na igreja matriz de outro município.

Na sequência do processo judicial, o assalto foi julgado improcedente e coube à mitra diocesana de Jacarezinho, principal cidade da região à época, decidir o destino da imagem. Em inícios de 1934, dom Fernando Taddei, bispo responsável, mandou doar a imagem do santo para a igreja matriz de Siqueira Campos.

Todo o incidente foi rapidamente esquecido. Razão lógica: mais importante que a imagem é o que ela representa. Tudo que se tem dito e escrito sobre o assunto desde então tem recaído sobre o místico. A contribuição decisiva de Anderson Lino, dos historiadores mais criativos de sua geração formada nos últimos dez anos na Faculdade de Filosofia e Letras de Jacarezinho da Universidade Estadual do Norte do Paraná, é justamente pôr história naquilo que a fé e a devoção de fiéis e infiéis insistem em desconsiderar. Nesse intento, seu êxito é absoluto.

Apesar de todo empenho e agudeza, o estudo de Anderson Lino deixa pontos cegos. Não fica clara a origem da imagem. São reproduzidas versões fantasmagóricas e fantásticas, mas não se evidencia se ela foi mesmo obra de Aleijadinho, feita nas Minas Gerais setecentistas, ou de algum escravo fujão, morador de São Paulo ou Paraná, com algum talento para escultura. Os causos que o povo conta são interessantes e importantes na 
tessitura do argumento do livro. Mas sem maior e mais detida avaliação, causos não passam de causos. A procedência da família Pinto e das demais famílias pioneiras na ocupação do norte velho do Paraná precisava ser mais bem esquadrinhada. Muito se fala e escreve sobre essa parte da província de São Paulo que se emancipou em província do Paraná em 1853, mas a impressão é que pouco ou nada se sabe em profundidade de como essa nova província se transformou num dos Estados mais importantes do Brasil ao longo do século 20 .

Afora uma ou outra imprecisão banal que pode ser facilmente reparada em uma segunda edição, duas divergências conceituais ao estudo podem fazer avançar a discussão. $\mathrm{O}$ arranjo sagrado e profano, que baliza toda a análise, tende a empobrecer a abordagem. A dinâmica de acomodação e contemporização da sociedade brasileira possui complexidade tamanha que não pode caber nessa gaiola sociologizante. Uma segunda observação sugere maior prudência na utilização da noção de regional. A história por trás da história dos passos da imagem do santo envolve ampla e difícil trama de eventos e fenômenos por toda parte em diferentes continentes que, mais que supostos, precisam ser explicitados para conferir inteligibilidade à eventual especificidade do que se diz regional ou local. Para além da falência do balance of power europeu que desembocou nas guerras mundiais, o posicionamento da igreja católica diante daquele ambiente em mudança estabeleceu rediscussões sobre a fé e o culto que impactaram seriamente sobre todas as dimensões de seus domínios. E, claramente, no Brasil, que era, e continua, majoritariamente católico. Em outras palavras, a imagem do santo que está em Siqueira Campos só tem de específico estar em Siqueira Campos. Difícil supor a quantidade de imagens que tiveram o mesmo fim em outras localidades mundo afora. Certamente muitas. O Senhor Bom Jesus siqueirense faz parte da história de todas elas. Isso não se deve menosprezar.

Recebido em março de 2012.

Aprovado em maio de 2013. 